\title{
Gonntagsfeier
}

unไ

\section{Gonntagsrube in Bayern}

unfer Berürkfirhftgung

der einscblägigen Gesetze und Jerordnungen etc.

pon

\section{Dr. jur. Cbristian Roth,}

Redifzpraktikant.

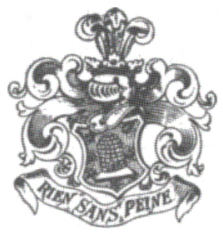

münchen.

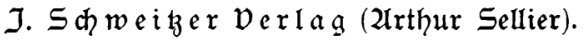

1899. 
Dr. Sranz Paul Datterer \& Cie., б. m.b. J., München. 